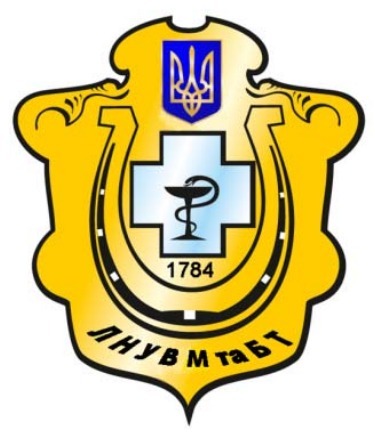

Науковий вісник Львівського національного університету ветеринарної медицини та біотехнологій імені С.3. Гжицького

Scientific Messenger of Lviv National University of Veterinary Medicine and Biotechnologies named after S.Z. Gzhytskyj

doi:10.15421/nvlvet7737

ISSN 2518-7554 print

ISSN 2518-1327 online

http://nvlvet.com.ua/

\title{
УДК 619:616.9-036
}

\section{Гематологічні та біохімічні показники крові собак, уражених коронавірусним ентеритом}

\author{
М.Л. Радзиховський \\ nickvet@ukr.net
}

Житомирський національний агроекологічний університет, вул. Корольова, 39, м. Житомир, 10025, Україна

\begin{abstract}
В загальній патології собак ентеровірусні інфекції иуценят посідають провідне місце, а особливе занепокоєння викликають хвороби змішаної етіології, що перебігають з нетиповими проявом клінічних ознак. У статті наведені морфологічні та біохімічні показники крові породних та безпородних собак, інфікованих коронавірусним ентеритом. Експеримент проводили у ветеринарних клініках міста Житомира, упродовж останніх двох років, за визначений період під час проведення лабораторних досліджень в ІФА та ПЛР було виявлено 10 собак, інфікованих вірусом родини Согопаviridae. У хворих на

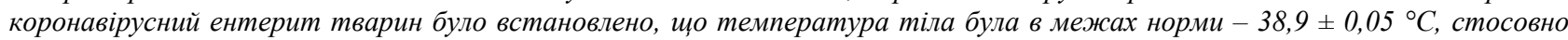
клінічних ознак - то вони характеризувались типовим проявом ентериту. Стосовно морфологічних та біохімічних показників - спостерігається зменшення кількості лейкоцитів (лейкоциитопенія) на 46\%, еритроцитів (еритроцитопенія) на $5 \%$ i лімфоцитів (лімфоцитопенія) на 13\% та зменшення гематокритної величини на 5\% нижче від мінімальної межі норми, підвищення активності лужної фосфатази і збільшення швидкість осідання еритрочитів в крові та відмічали зсув лейкоцитарної формули вправо за рахунок підвищенням кількості сегментованих ядерних форм нейтрофілів. У собак при даній патології вражається печінка, про шео свідчить зменшення рівня загального білка на 23\% порівняно з мінімальними значеннями норми.
\end{abstract}

Ключові слова коронавірусний ентерит собак, стабілізована кров, сироватка крові, еритроцитопенія, лейкоцитопенія, лімфоцитопенія, гіпопротенемія, лужна фосфатаза.

\section{Гематологические и биохимические показатели крови собак, больных коронавирусным энетритом}

\author{
Н.Л. Радзиховский \\ nickvet@ukr.net
}

Житомирский начиональный агроэкологический университет, ул. Королева, 39, г. Житомир, 10025, Украина

В общей патологии собак энтеровирусные инфекиии щенков занимают ведущее место, а особенную обеспокоенность вызывают болезни смешанной этиологии, которые протекают с нетипичным проявлением клинических признаков. В статье, приведены морфологические и биохимические показатели крови породных и беспородных собак, инфицированных коронавирусным энтеритом. Эксперимент проводили в ветеринарных клиниках города Житомира на протяжении последних двух лет, за определенный период во время проведения лабораторных исследований в ИФА и ПЦР было выявлено 10 собак, инфицированных вирусом семейства Согопаviridaе. У больных коронавирусным энтеритом животных было установлено, что температура тела была в пределах нормы - 38,9 $\pm 0,05{ }^{\circ} \mathrm{C}$, относительно клинических признаков - они характеризовались типичным проявлением энтерита. Относительно морфологических и биохимических показателей наблюдается уменьшение количества лейкоцитов (лейкоцитопенія) на 46\%, эритроцитов (эритроцитопеиія) на 5\% и лимфоцитов (лимфоцитопения) на 13\% и уменьшение величины гематокрита на 5\% ниже минимального предела нормы, повышение актив-

Radsikhovskii, N. (2017). Haematological and biochemical indices of blood in dogs with coronavirus enteritis. Scientific Messenger LNUVMBT named after S.Z. Gzhytskyj, 19(77), 170-173. 
ности щуелочной фосфатазы и увеличение скорости оседания эритроцитов в крови и отмечали сдвиг лейкоцитарной формуль вправо за счет повышениям количества сегментоядерных форм нейтрофилов. У собак при данной патологии поражается печень, о чем свидетельствует уменьшение уровня общего белка на 23\% сравнительно с минимальными значениями нормы.

Ключевые слова коронавирусный энтерит собак, стабилизированная кровь, сыворотка крови, эритроцитопения, лейкоцитоопени, лимфоцитопения, гипопротенемия, щуелочная фосфатаза.

\title{
Haematological and biochemical indices of blood in dogs with coronavirus enteritis
}

\author{
N. Radsikhovskii \\ nickvet@ukr.net
}

\begin{abstract}
Zhytomyr National Agroecological University, Korolova Str., 39, Zhytomyr, 10025, Ukraine
\end{abstract}

\begin{abstract}
In general pathology of dogs the enterovirus infections of puppies occupy a leading place, and the special disturbance is caused by illnesses of the mixed etiology, that run across with off type the display of clinical signs. The goal of the work was to identify the hematological and biochemical change in the blood of dogs sick with coronavirus enteritis. To confirm canine coronavirus was used VetExpert rapid tests in the veterinary clinics of Zhytomir and as well as positive results of private laboratory Bald Ltd. (Kyiv). Hematological and biochemical researches were made by biochemical analyzer BioChem SA with chemical of High Technology Inc. (USA). Where analyzed in blood amount of RBC, WBC, leucogram, hemoglobin, hematocrit, speed of erythrocyte sedimentation by electronic-automatic method. In serum blood detected common protein by biuretic method, urea by fermentation method, creatinine by Jaffe method, common calcium by comlexone Arsonaso-3, nonorganic phosphorus by phosphomolibdate method, glucose by fermentation method. Activity of Asparagine and Alanine aminotranpedase (AsAT and AlAT) by method of Reitmann-Frenkel, alkaline phosphatase be kinetic method. In 2014-2016 were found and confirmed diagnosis coronavirus enteritis in 10 dogs. The temperature of their body was under the normal condition. In relation to morphological and biochemical indexes then there is reduction to the amount of leucocytes on $46 \%$, erythrocytes on $5 \%$ and lymphocytes on $13 \%$ and by reduction of hematocrit on $5 \%$ below minimum limit of norm, increase of activity alkaline phosphatase and increase speed of settling of red corpuscles in blood and marked the change of leucocytes formula to the right for an account to the increases of amount of the segmented nuclear forms of neutrophil. For dogs at this pathology a liver is struck, to what reduction of level general testifies squirrel on $23 \%$ comparatively with the minimum values of norm. Perspective is a further study of the state of blood, namely-leucocytes profile for deeper research of pathological processes in the organism of dogs, patients with coronavirus enteritis.
\end{abstract}

Key words: coronavirus enteritis of dogs, steady-state blood, serum of blood, erythropenia, leykotsitopeniya, hypolymphemia, hypoproteinemia, alkaline phosphatase.

\section{Вступ}

В останні роки в Україні інтенсивно розвивається службове, декоративне та мисливське собаківництво. Щорічно збільшується поголів'я собак, сприйнятливих до різних інфекційних захворювань, серед яких особливе занепокоєння викликають хвороби змішаної етіології, що перебігають 3 нетиповим проявом клінічних ознак для відповідних інфекцій (Fasolia, 2001; Medova et al., 2005). Вірусні захворювання сьогодні знаходяться - у стадії глибокого вивчення. Ветеринарні і медичні вірусологи постійно відкривають все нових збудників, у міру розвитку сучасних технологій i отримання нових знань в цій ділянці. Коронавірус у собак - не виняток. Цей різновид збудника вірусної інфекції відкрили в 1971 році у Німеччині, коли дослідники звернули увагу на характерні клінічні ознаки ентериту у вівчарок, які однаково протікали у всіх тварин в межах розплідника.

Вірусні ентерити призводять до тяжких розладів таких систем, як шлунково-кишкової, серцевосудинної та дихальної. Дорослі собаки рідко хворіють на ентерити такої етіології і в більшості випадків 3 позитивним прогнозом. Смертельну небезпеку ентерити вірусної етіології становлять для цуценят. Не вакцинований молодняк отриманий від неімунних собак в умовах розплідників, хворіє важко зі значною летальністю: від 30 до $80 \%$.

В Україні ж питання обов'язкової специфічної профілактики і ліквідації вірусних захворювань собак ніколи серйозно не ставилося. Необхідність вакцинації носить досі рекомендаційний характер. Масштаби і наслідки вірусних захворювань собак були, $є$ i, можливо, будуть завжди проблемою собаківників (Fasolia, 2008).

Комплексна діагностика цієї патології у собак розроблена недостатньо. Висока варіабельність клінічних ознак за коронавірусного ентериту, складність апеляції великим числом якісних показників ускладнюють постановку діагнозу на це захворювання для практичного ветеринарного лікаря (Vahrushev and Shkatova, 2007).

Таким чином, комплексне вивчення клінічних змін і показників крові у собак, хворих на коронавірусний ентерит $\epsilon$ актуальним і потрібним для покращення комплексу діагностичних маркерів.

Метою роботи було виявити морфологічні та біохімічні зміни в крові собак, хворих на коронавірусний ентерит.

\section{Матеріал і методи досліджень}

Робота виконувалась на факультеті ветеринарної медицини Житомирського національного агроекологічного університету (ЖНАЕУ), а також у ветеринар- 
них клініках міста Житомира: приватних ветеринарних клініках «Багіра» і «Доктор-Zоо», навчальнонауково-виробничій клініці ветеринарної медицини факультету ветеринарної медицини ЖНАЕУ та в міській державній лікарні ветеринарної медицини м. Житомира (період з 2014 по 2016 рік) на породних і безпородних собаках.

Діагностичні дослідження на підтвердження коронавірусного ентериту проводили за допомогою експрес-тестів VetExpert та в приватній ветеринарній лабораторії ТОВ «Бальд» (м. Київ). Гематологічні та біохімічні дослідження проводили за допомогою біохімічного аналізатора BioChem $S A$ із застосуванням реактивів фірми High Tehnology, Inc. (США). Підрахунок еритроцитів, лейкоцитів та лейкограми, гемоглобіну, гематокритної величини та швидкість осідання еритроцитів (ШОЕ) проводили електронноавтоматичним методом. У сироватці крові визначали загальний протеїн - біуретовим методом, сечовини ферментативним методом, креатиніну - методом Яффе, загального кальцію - 3 комплексоном Арсеназо-3, неорганічного фосфору - фосфомолібдатним методом, глюкози - ферментативним. Активність аспарагінової та аланінової амінотранспептидаз (АсАТ і АлАТ) визначали методом Райтмана-Френкеля, лужної фосфатази - кінетично (Sukmanskyi, 2009). Цифрові дані обробляли біометрично загальноприйнятими методами варіаційної статистики 3 використанням комп'ютерних програм Statistika 6.0 та Microsoft Excel 2007 (Kochetov et al., 2012).

\section{Результати та їх обговорення}

Для дослідження були відібрані собаки з характерними клінічними ознаками хвороби та обов'язковим підтвердженням діагнозу одним із методів: експрестест або лабораторно - шляхом ПЛР або ІФА і виявлення антигену.

За 2014-2016 рр. було виявлено та підтверджено діагноз на коронавірусний ентерит у 10 собак. Встановлено, що температура тіла хворих тварин була в межах норми $-38,9 \pm 0,05{ }^{\circ} \mathrm{C}$. У собак були відібрані зразки крові для морфологічних і біохімічних досліджень.

У хворих собак відзначали зниження кількості еритроцитів. Причиною цього, на нашу думку, був інфекційний агент у крові хворих, що викликав гемоліз червоних кров'яних клітин (табл. 1).

Гематокритна величина у інфікованих тварин була дещо нижчою від норми, що відповідало стану собак, у яких відмічали дегідратацію внаслідок проносу. У хворих собак відмічали виражену лейкоцитопенію. Цей факт пов'язаний $з$ тим, що вірус розмножується швидким діленням в клітинах кісткового мозку, а саме - лейкоцитах. Частка еозинофілів і моноцитів в межах норми. Відмічали зниження лімфоцитів, що $\epsilon$ характерним для гострих інфекційних процесів.

3 даних таблиці (табл. 1) відмічаємо зсув лейкоцитарної формули вправо за рахунок підвищення кількості сегментованих ядерних форм нейтрофілів. Лімфоцитопенія, можливо, була викликана низькомолекулярними білками - інтерферонами, які синтезуються у відповідь на вірусну інфекцію (Kishkun, 2014). Швидкість осідання еритроцитів у крові інфікованих збудником коронавірусного ентериту тварин була вищою за норму. Причиною цього є збільшення концентрації в плазмі білків гострої фази, а саме: фібриногену, С-реактивного білка та імуноглобулінів (Mejer and Harvi, 2007).

Концентрація гемоглобіну, вміст кальцію, фосфору, глюкози, сечовини й креатиніну в хворих тварин не виходили за межі фізіологічних коливань (табл. 2).

Водночас слід відзначити, що вміст глюкози та креатиніну у хворих на коронавірусний ентерит собак $\epsilon$ нестабільним показником. Проте середнє значення було в межах норми. Вміст загального білка за коронавірусного ентериту в собак знижувався, оскільки у хворих собак відмічали зниження апетиту. Білок до організму надходив у недостатній кількості та враховуючи ураження кишечнику, практично не всмоктувався в ньому. Гіпопротеїнемія відображає процеси ураження печінки, оскільки більшість його фракцій синтезується гепатоцитами (Hariv and Gutyj, 2016; Khariv et al., 2016).

Проведені комплексні дослідження показали, що в собак, хворих на коронавірусний ентерит, характерними є зміни морфологічного та біохімічного складу крові (табл. 2). Було встановлено еритроцитопенію, лейкоцитопенію, лімфоцитопенію, гіпопротеїнемію, збільшення ШОЕ.

Таблиия 1

Морфологічні показники крові собак, інфікованих збудником коронавірусного ентериту, $\mathbf{M} \pm \mathbf{m}, \mathbf{n}=10$

\begin{tabular}{|c|c|c|c|c|}
\hline \multicolumn{2}{|c|}{ Показники } & Одиниці виміру & Норма & Хворі собаки \\
\hline \multicolumn{2}{|l|}{ Еритроцити } & Т/л & $5,5-8,5$ & $5,20 \pm 1,34$ \\
\hline \multicolumn{2}{|c|}{ Гематокритна величина } & $\%$ & $37-55$ & $35,2 \pm 5,4$ \\
\hline \multicolumn{2}{|l|}{ Тромбоцити } & Г/л & $150-500$ & $343,6 \pm 134,04$ \\
\hline \multicolumn{2}{|l|}{ Лейкоцити } & Г/л & $8,5-10,5$ & $4,606 \pm 0,98$ \\
\hline \multirow{2}{*}{ нейтрофіли } & $\Pi$ & $\%$ & $1-6$ & $1,66 \pm 1,44$ \\
\hline & $\mathrm{C}$ & $\%$ & $40-71$ & $73,6 \pm 5,77$ \\
\hline \multicolumn{2}{|l|}{ Еозинофіли } & $\%$ & $2-9$ & $3,0 \pm 0,81$ \\
\hline \multicolumn{2}{|l|}{ Моноцити } & $\%$ & $1-5$ & $1,75 \pm 0,95$ \\
\hline \multicolumn{2}{|l|}{ Лімфоцити } & $\%$ & $21-40$ & $18,4 \pm 4,22$ \\
\hline \multicolumn{2}{|l|}{ ШОЕ } & мм/год. & $2,0-5,0$ & $7 \pm 1,41$ \\
\hline
\end{tabular}


Біохімічні показники у собак, інфікованих коронавірусним ентеритом, $\mathrm{M} \pm \mathbf{m}, \mathbf{n}=\mathbf{1 0}$

\begin{tabular}{|c|c|c|c|}
\hline Показники & Одиниці виміру & Норма & Хворі собаки \\
\hline Глюкоза & ммоль/л & $3,4-6$ & $3,39 \pm 0,57$ \\
\hline Білірубін загальний & мг/л & $0-5$ & $2 \pm 0,28$ \\
\hline Калій & ммоль/л & $1,87-2,8$ & $2,435 \pm 0,44$ \\
\hline Кальцій & ммоль/л & $0,68-2$ & $1,45 \pm 0,07$ \\
\hline Фосфор & ммоль/л & $0,8-1$ & $0,8 \pm 0,14$ \\
\hline Магній & ммоль/л & $10-150$ & $310,8 \pm 63,35$ \\
\hline Лужна фосфатаза & од/л & $120-180$ & $131,04 \pm 27,15$ \\
\hline Нь (гемоглобін) & г/л & $51-78$ & $39,55 \pm 12,37$ \\
\hline Загальний білок & Г/л & $5-55$ & $26,7 \pm 6,08$ \\
\hline АсАТ & од/л & $9-75$ & $36,75 \pm 6,43$ \\
\hline АлАТ & од/л & $3,5-9,2$ & $4,205 \pm 0,41$ \\
\hline Сечовина & ммоль/л & $26-120$ & $48,8 \pm 27,15$ \\
\hline
\end{tabular}

Зміни біохімічних показників не є неспецифічними, проте відображають глибину патологічних процесів, які ускладнюють перебіг коронавірусного ентериту. Одержані нами результати збігаються 3 даними літератури і показали, що в інфекційний процес втягується печінка.

\section{Висновки}

1. Коронавірусний ентерит у собак характеризується зменшенням кількості лейкоцитів на 46\%, еритроцитів на $5 \%$ і лімфоцитів на $13 \%$ та зменшенням гематокритної величини на 5\% нижче за мінімальну межу норми.

2. За коронавірусного ентериту у собак вражається печінка, про що свідчить зменшення рівня загального білка на 23\% порівняно з мінімальними значеннями норми.

3. Захворювання характеризується гіперактивністю лужної фосфатази вдвічі порівняно із максимальними значеннями нормативу.

Перспективним є подальше вивчення стану крові, а саме - лейкоцитарного профілю для більш глибокого дослідження патологічних процесів в організмі собак, хворих на коронавірусний ентерит.

\section{Бібліографічні посилання}

Medova, E.V., Mamleeva, D.A., Pivovarenko, E.A. (2005). Domashnie plotojadnye kak populjacii jepidemicheskogo - jepizooticheskogo riska na urbanizirovannyh territorijah. Vet. patologija. 4, 134 137 (in Russian).

Fasolia, V.P. (2001). Struktura vnutrishnikh khvorob sobak u m. Zhytomyri. Visnyk Bilotserkiv. derzh. ahrar. un-tu. Bila Tserkva. 18, 158-163 (in Ukrainian).
Fasolia, V.P. (2008). Dyspanseryzatsiia sobak sluzhbovykh porid: avtoref. dys. ... doktora vet. nauk: spets. 16.00.01 «Diahnostyka i terapiia tvaryn». Bila Tserkva, 38 (in Ukrainian).

Vahrushev, Ja.M., Shkatova, E.Ju. (2007). Laboratornye metody diagnostiki. Rostov-na-Donu: Feniks (in Russian).

Sukmanskyi, O.I. (2009). Veterynarna hematolohiia: Navchalnyi posibnyk dlia studentiv vyshchykh navchalnykh zakladiv. Odesa: VMV (in Ukrainian).

Kochetov, A.G., Ljang, O.V., Masenko, V.P., Zhirov, I.V., Nakonechnikov, S.N., Tereshhenko, S.N. (2012). Metody statisticheskoj obrabotki medicinskih dannyh: Metodicheskie rekomendacii dlja ordinatorov i aspirantov medicinskih uchebnyh zavedenij, nauchnyh rabotnikov. M.: RKNPK (in Russian).

Kishkun, A.A. (2014). Biohimicheskie issledovanija v klinichesk oj praktike: Rukovodstvo dlja vrachej. M.: OOO «Izdatel'stvo «Medicinskoe informacionnoe agenstvo» (in Russian).

Hariv, M.I., Gutyj, B.V. (2016). Influence of the liposomal preparation Butaintervite on protein synthesis function in the livers of rats under the influence of carbon tetrachloride poisoning. Visnyk of Dnipropetrovsk University. Biology, medicine. 7(2), 123-126. doi: 10.15421/021622.

Khariv, M., Gutyj, B., Butsyak, V., Khariv, I. (2016). Hematological indices of rat organisms under conditions of oxidative stress and liposomal preparation action. Biological Bulletin of Bogdan Chmelnitskiy Melitopol State Pedagogical University. 6 (1), 276-289. doi: http://dx.doi.org/10.15421/201615

Mejer, D., Harvi, Dzh. (2007). Veterinarnaja laboratornaja medicina. Interpritacija i diagnostika. Per. s angl. M.: Sofion (in Russian).

Стаття надійшла до редакиії 27.03.2017 